\title{
CONTROLLED OPENNESS AND FOREIGN DIRECT INVESTMENT
}

\author{
Joshua Aizenman \\ Sang-Seung Yi
}

Working Paper 6123

\author{
NATIONAL BUREAU OF ECONOMIC RESEARCH \\ 1050 Massachusetts Avenue \\ Cambridge, MA 02138 \\ August 1997
}

The financial support from the Rockefeller Center for the Social Sciences at Dartmouth College is gratefully acknowledged. This paper is part of NBER's research program in International Trade and Investment. Any opinions expressed are those of the authors and not those of the National Bureau of Economic Research.

(C) 1997 by Joshua Aizenman and Sang-Seung Yi. All rights reserved. Short sections of text, not to exceed two paragraphs, may be quoted without explicit permission provided that full credit, including $(\mathcal{C}$ notice, is given to the source. 
Controlled Openness and Foreign Direct Investment

Joshua Aizenman and Sang-Seung Yi

NBER Working Paper No. 6123

August 1997

JEL Nos. F15, F21

International Trade and Investment

\begin{abstract}
The purpose of this paper is to offer an explanation of why a developing country may adopt a partial reform under which foreign direct investments are controlled. We consider a country where the ruling elite [referred to as State capital] prevents the entry of Foreign capital and taxes the private sector before reform. The impetus to reform comes from an improved productivity of Foreign capital. The reform diminishes State capital's ability to tax the private sector but allows it to extract payment from Foreign capital for access to its markets. We show that a higher productivity of Foreign capital always increases the attractiveness of a partial reform under which State capital can control the inflow of Foreign capital. In contrast, a higher productivity of Foreign capital can reduce the attractiveness of a full reform under which the entry of Foreign capital is unregulated. Our analysis implies that, under the circumstances where the impetus to reform comes from improvements in Foreign productivity, State capital's exercise of control over Foreign capital's inflow may be a necessary condition for the reform to take place at all. In the absence of such a control, State capital may be reluctant to carry out the efficiency-enhancing reforms.
\end{abstract}

Joshua Aizenman

Department of Economics

Dartmouth College

Hanover, NH 03755

and NBER

J.Aizenman@dartmouth.edu
Sang-Seung Yi

Department of Economics

Dartmouth College

Hanover, NH 03755

San-Seung.Yi@dartmouth.edu 


\title{
Controlled Openness and Foreign Direct Investment
}

\author{
by Joshua Aizenman and Sang-Seung Yi
}

\section{Introduction and Summary}

The last decade has been both a challenging and an exciting period for developing and formerly communist countries. In numerous cases, they have scrapped old protective policies that encouraged inward orientation and adopted instead a friendlier attitude towards international trade. To encourage foreign direct investment and to promote linkages with the global financial community, they have reclassified and even courted multinationals and international organizations that were previously viewed as colonialist agents.

These developments may signal a new international order, one in which the cost of isolationist domestic policies is prohibitive, while access to markets, foreign direct investment, and modern technologies determine the stance of domestic policies. This paper investigates the key role played by these outside opportunities and outside challenges in inducing the ruling elite in developing or formerly communist countries to adopt an outward-oriented, efficiency-enhancing reform.

A large body of recent literature explores how rivalry among interest groups functions as an impetus to regime changes. For example, Alesina and Drazen (1991) studied the timing of stabilization by formulating a war-of-attrition game among competing groups with private information about their costs of bearing the burden of stabilization. The competing groups attempt to minimize their postreform tax burden. In their model, reforms usually result in the emergence of a winning group that imposes a disproportionate share of the costs of reforms on the 
other parties. Furthermore, a deeper crisis results in an earlier stabilization. Thus, reforms tend to occur during bad times. 1

While such models are instructive, they emphasize competition among groups, and thus ignore the possibility that some reforms may occur from within the ruling coalition. Indeed, a monolithic ruling elite sometimes initiates reforms which may ultimately jeopardize its power. For example, both in China and in South Africa, the ruling class embarked on the reform path as the optimal strategy against threats that would materialize in the absence of reforms. Even if the reform leads to a loss of power over time (as the South African example illustrated), a forward-looking ruling class may embark on the reform path if it expects an earlier or more complete loss of power in the absence of reforms.

This paper studies the forces inducing domestic authorities to open up the economy to Foreign capital and international trade in circumstances where the old regime maintains enough power to dictate the speed of reform. We construct a model of the reform process and identify the importance of external factors, in particular the improvements in foreign productivity, encouraging a reform. We evaluate the authorities' incentives, in the reforming country, to bargain with the owners of Foreign capital, instead of allowing the invisible hand of market forces to determine the distribution of surpluses. ${ }^{2}$

1 Further discussion on alternative approaches explaining reforms and obstacles to reforms see Fernandez and Rodrik (1991), Wei (1992), Rodrik (1992) and Tornell (1993). Rodrik (1996) provides an excellent survey of the recent literature.

2 Of course, "reform from within" is not a wholly new idea. For example, in a political economy model Hillman (1982) showed that a world price shock induces an endogenous change in the level of import protection. Feldman and Gang (1996) 
Adopting the reform results in trade-offs for the ruling elite. First, any reform allowing Foreign capital into the country weakens the ability of State capital to control the domestic private sector. Second, the inflow of Foreign capital directly affects the marginal productivity of State capital owned by the ruling elites. Third, the reform enables the ruling elite to exert a degree of control over Foreign capital. Exercising this control requires the ruling elite to forego a more thorough market reform which allows the market forces to allocate resources. Instead, through negotiation, the ruling elite imposes its own non-competitive distribution of the surplus attributed to State and Foreign capital.

In this setting, we evaluate the impact of improved foreign productivity on the ruling elite's incentives to introduce a market-opening reform in two regimes: the "bargaining regime" and the "competitive regime". In the competitive regime, the ruling elite introduces a full market reform so that it does not exercise any control on the inflow of Foreign capital. In contrast, in the bargaining regime, negotiations between State and Foreign capital determine the inflow of foreign direct investment. As one can expect, the inflow of Foreign capital in the bargaining regime falls short of the level in the competitive regime, resulting in efficiency losses.

Nonetheless, we show that the ruling elite is more willing to adopt a marketopening reform in the bargaining regime than in the competitive regime. In the bargaining regime, an increase in the productivity of Foreign capital increases the income gain to the ruling elite from the reform independently of the

showed that revenue motives may induce an elite to reform its trade policy following a terms of trade shock. The present paper's novelty is its extension of the "reform from within" idea to capital flows, explaining the ruling elite's desire to control both the income and the inflow of foreign capital. 
substitutability/complementarity patterns between Foreign capital and State capital. This is in sharp contrast to the outcome in the competitive regime. There, the inflow of Foreign capital reduces State capital's income if Foreign capital is a substitute for State capital. Hence, in the competitive regime, the ruling elite's incentives to introduce a market-opening reform depends on the substitutability/complementarity patterns between Foreign capital and State capital. The fundamental difference between these two regimes is that State capital can share the extra income generated by the improved foreign productivity through taxation under the bargaining regime, but it cannot under the competitive regime where it does not have the ability either to control or tax the inflow of Foreign capital. Hence, under the circumstances where the impetus to reform comes from improvements in foreign productivity, State capital's exercise of control over the inflow of Foreign capital may be a necessary condition for the reform to take place at all. In the absence of such a control, State capital may be reluctant to carry out the efficiency enhancing reforms. 


\section{The model}

There are two classes of domestic inputs. Prior to the reform, one class of domestic inputs is "in control," having the ability to tax the second class of inputs. We refer to this first category of inputs as State capital (or alternatively the ruling elite), and to the second as the private sector. Before reform, State capital follows inward-oriented policies. We model these policies as tight restrictions on foreign direct investment. Reform involves a switch to outward orientation, allowing foreign direct investment and eliminating the private sector tax.

We turn now to a brief description of production and compensation. Aggregate production before reform is

$$
Y=L^{1-\alpha}\left(A_{d} K_{d}\right)^{\alpha}
$$

where $L$ is the domestic private sector, and $K_{d}$ is State capital the productivity of which is $A_{d} .{ }^{3}$ The share of State capital $(\alpha)$ is assumed to be smaller than half, as is suggested by the GNP data. To simplify exposition, we assume that the size of State capital is exogenously given.

Reform opens the economy to Foreign capital, so that the production function becomes

$$
\tilde{Y}=L^{1-\alpha}\left[\left(A_{d} K_{d}\right)^{\rho}+\left(A_{f} K_{f}\right)^{\rho}\right]^{\alpha / \rho}
$$

3 To simplify the analysis we lump the domestic private capital, entrepreneurs and labor into one aggregate input, called the domestic private sector.

Disaggregating the analysis into various domestic inputs will complicate the notation, but will not affect the key results as long as the state sector applies similar policies to all the private inputs. 
where $K_{f}$ is Foreign capital, the productivity of which is $A_{f}$, and $\tilde{x}$ stands for the post-reform value of a variable $x$. When $\alpha<\rho \leq 1$, Foreign and State capital are "substitutes": the entry of Foreign capital reduces the marginal productivity of State capital and thus of State capital income. On the other hand, if $0<\rho<\alpha$, they are "complements": the presence of Foreign capital increases the marginal product of State capital. When $\rho=\alpha$, they are "neutrals": the marginal productivity of State capital is not affected by Foreign capital (Romer 1994). ${ }^{4}$ On the other hand, the inflow of Foreign capital always increases both the marginal productivity of the domestic private sector and total output, regardless of the substitutability/complementarity pattern of Foreign and State capital. Our formulation captures the possible conflicts of interest between State capital and the domestic private sector in opening up the economy.

In the absence of a reform, State capital taxes the private sector. We assume that the equilibrium tax rate is determined by the Nash bargaining solution $\theta_{b}$ which solves

$$
\begin{aligned}
& \operatorname{MAX}[\theta Y-0][(1-\theta) Y-0] \\
& \theta
\end{aligned}
$$

the solution of which is given by $\theta_{b}=1 / 2$. Hence, State capital's income in the absence of the reform, denoted by $U_{n}$, is equal to

$$
U_{n}=\theta b Y=0.5 Y
$$

The required tax rate $\tau_{n}$ is equal to $[1-2 \alpha] /[2(1-\alpha)]$.

$4 \quad$ This follows from the fact that $\frac{\partial^{2} \tilde{Y}}{\partial K_{f} \partial K_{d}}>0$ if and only if $\alpha>\rho$. 


\section{Undertaking Reforms: the Competitive Regime}

Let $r_{f}$ denote the exogenously given yield on Foreign capital, and let $r_{d}$ and $\tilde{r}_{d}$ represent the rental cost of State capital before and after reform, respectively.

When a full reform occurs, the amount of Foreign capital inflow is defined by

$$
r_{f}=\alpha\left(A_{f}\right)^{\rho} L^{1-\alpha}\left[\left(A_{d} K_{d}\right)^{\rho}+\left(A_{f} K_{f}\right)^{\rho}\right]^{\frac{\alpha}{\rho}-1}\left(K_{f}\right)^{\rho-1},
$$

which equates the marginal productivity of Foreign capital with the exogenous foreign yield on capital. The distributive share of Foreign capital income out of the GNP is $s_{f}=\alpha \kappa_{f}$ where $\kappa_{f}=\left(A_{f} K_{f}\right)^{\rho} /\left[\left(A_{d} K_{d}\right)^{\rho}+\left(A_{f} K_{f}\right)^{\rho}\right]$. The value of $\kappa_{f}$ measures the relative effective share of Foreign capital in the total stock of capital. Similarly, the distributive share of State capital is $\mathrm{s}_{d}=\alpha \kappa_{d}$, where $\kappa_{d}=1-\kappa_{f}$.

Opening the economy reduces State capital's ability to tax the private sector. For example, if opening the domestic market occurs through signing an international agreement, such as free trade agreements or the General Agreement on Tariffs and Trade (GATT), a signatory country may be bound to eliminate any domestic subsidies to domestic capital. Alternatively, the loss of "control" for State sector may be also due to the inability to enforce the collection of taxes on income generated in activities outside the direct control of State capital, as may be the case with multinationals and an emerging private sector. Since State capital must compete with Foreign capital for the domestic private sector, taxing the private sector may put it in a disadvantageous position. In what follows we assume that, due to these factors, a reform involves eliminating the taxation of the private 
sector. $^{5}$ Hence, State capital income after a full reform in the competitive regime, denoted by $U_{c}$, is equal to

$$
U_{c}=\alpha \kappa_{d} \tilde{Y}=\alpha\left(K_{d} A_{d}\right)^{\rho} L^{1-\alpha}\left[\left(K_{d} A_{d}\right)^{\rho}+\left(K_{f} A_{f}\right)^{\rho}\right]^{(\alpha-\rho) / \rho} .
$$

Note that $U_{c} \underset{A_{f} \rightarrow 0}{\longrightarrow} \alpha L^{1-\alpha}\left(K_{d} A_{d}\right)^{\alpha}=\alpha Y$. Thus, for low enough foreign productivity, $U_{c}<U_{n} .6$ Intuitively, when foreign productivity is very low, very little Foreign capital enters even under a full reform. Hence, both total output and State capital's marginal productivity are almost unaffected by allowing the inflow of Foreign capital. Because State capital loses its ability to tax the private sector after reform, State capital does not find a full reform profitable when foreign productivity is very low even when there is a high degree of complementarity between State and Foreign capital.

Throughout the paper we assume that foreign productivity is initially low enough so that State capital is initially reluctant to institute a reform regardless of the substitutability/complementarity patterns between State and Foreign capital. We then focus on how improvements in foreign productivity affect the willingness of the State capital to implement reforms under the competitive and bargaining regimes. A comparison of State capital's incomes under no reform and under a full reform establishes

$5 \quad$ Our main results do not depend on this simplifying assumption. As will become clear, what we need is that the taxation rate decreases when a reform takes place.

6 Recall that $U_{n}=0.5 Y$, and that $\alpha<1 / 2$ by assumption. 
Proposition 1: A higher productivity of Foreign capital makes a full reform more attractive (vis-a-vis no reform) to State capital if and only if Foreign capital is complementary to State capital.

Proof. $U_{n}$ is not affected by $A_{f}$ and

$d U_{c} / d A_{f}=\partial U_{c} / \partial A_{f}+\left[\partial U_{c} / \partial K_{f}\right]\left[d K_{f} / d A_{f}\right]=(\alpha-\rho) \kappa_{f} U_{c}\left[\frac{1}{A_{f}}+\frac{1}{K_{f}} \frac{d K_{f}}{d A_{f}}\right]>0$ if and

only if $\alpha>\rho . \quad$ Q.E.D.

\section{Reform decisions: the Bargaining Regime}

We now turn to the case where the domestic authorities maintain control of the extent of Foreign capital inflow. The profit repatriation by Foreign capital is determined by its bargaining position vis-a-vis the authorities. ${ }^{7}$ We assume that, in case of conflict between State and Foreign capital, Foreign capital has the ability to shut off its use (leading to a zero income of Foreign capital), whereas State capital has the ability to revert to the old pattern of production, by forcing the

7 A recent anecdotal discussion of the discretionary nature of bargaining between the Chinese authorities and multinationals is The Economist (April 13, 1996, page 62) -- "Foreign companies in China remain even more unsure about the tariffs' potential impact. They should gain from being able to import more components into China. However, those planning new factories in China (i.e., virtually all of them) now face sharply higher bills. The loss of duty exemption on the machinery they will have to import could add as much as $40 \%$ to the cost of a venture. Already some are pleading for special treatment. ... America's GM is also grumbling... Zhu Rongju, Chain's vice premier, who late last year hinted that "exceptions" could be made for projects deemed important to China, is said to be on the case." 
domestic private sector to work only with State capital and divide the resulting income equally. These assumptions imply that the disagreement incomes are zero for Foreign capital and $0.5 Y$ for State capital. With equal bargaining power, State capital gets a share of $h_{b}$, determined by the outcome of the following maximization:

$$
\underset{h}{M A X}[h \alpha \tilde{Y}-0.5 Y][(1-h) \alpha \tilde{Y}-0] .
$$

which yields

$$
h_{b}=\frac{1}{2}\left[\frac{\alpha \tilde{Y}+0.5 Y}{\alpha \tilde{Y}}\right]
$$

The corresponding income of State capital, denoted by $U_{b}$, is

$$
U_{b}=h_{b} \alpha \tilde{Y}=\frac{1}{2}[\alpha \tilde{Y}+0.5 Y]
$$

(Foreign capital's gross income is equal to $\left(1-h_{b}\right) \alpha \tilde{Y}$.) Note that the inflow of Foreign capital increases the total capital surplus by $\alpha \tilde{Y}-0.5 Y$. This added surplus (when it is positive) is divided equally between State and Foreign capital.

From equation (9), one can learn that the equilibrium inflow of $K_{f}$ under a controlled reform is determined by solving the profit maximization

$$
\underset{K_{f}}{\operatorname{MAX}}\left[\frac{1}{2}[\alpha \tilde{Y}-0.5 Y]-K_{f} r_{f}\right]
$$

which leads to

$$
\frac{0.5 \alpha^{2} \kappa_{f} \tilde{Y}}{K_{f}}=r_{f}
$$

Foreign capital's net income, denoted by $F C$, is given by 


$$
F C=\frac{1}{2}\left[\alpha\left\{1-\alpha \kappa_{f}\right\} \tilde{Y}-0.5 Y\right]
$$

From a comparison of $U_{n}$ and $U_{b}$ we learn that the controlled reform under the bargaining regime increases State capital's income by

$$
U_{b}-U_{n}=\frac{1}{2}[\alpha \tilde{Y}-0.5 Y]
$$

In general, (13) may be negative so that State capital does not gain from the controlled reform. ${ }^{8}$ However, a comparison between the income gain of State capital and Foreign capital rent (equations (12) and (13)) shows that $U_{b}-U_{n}>F C$. Hence, if Foreign capital finds it worthwhile to invest in the reforming country, State capital benefits from the controlled reform. This result follows from the fact that, with equal bargaining power, State capital gets half of the gross capital rent generated by Foreign capital, without sharing the cost of investment by Foreign capital. The next result shows that an increase in the productivity of Foreign capital $\left(A_{f}\right)$ makes the controlled reform more attractive.

Proposition 2: A higher productivity of Foreign capital makes a controlled reform more desirable to both State and Foreign capital, independently of the patterns of substitutability between the two.

$8 \quad$ As in the paragraph preceding Proposition $1, U_{b}<U_{n}$ for low enough foreign productivity and for $\alpha<1 / 2$. The intuition for this result is analogous to the case of a full reform. Since very little Foreign capital enters the economy when foreign productivity is very low, the taxation of Foreign capital under the bargaining regime brings very little income to State capital. 
Proof. By the envelope theorem,

$$
\begin{aligned}
& \frac{d\left[\frac{1}{2}[\alpha \tilde{Y}-0.5 Y]-K_{f} r_{f}\right]}{d A_{f}}=\frac{\partial\left[\frac{1}{2}[\alpha \tilde{Y}-0.5 Y]-K_{f} r_{f}\right]}{\partial A_{f}}=\frac{\partial\left[\frac{1}{2}[\alpha \tilde{Y}]\right]}{\partial A_{f}}=\frac{0.5 \alpha^{2} \kappa_{f} \tilde{Y}}{A_{f}}>0 . \text { Thus, } \\
& \frac{d\left[\frac{1}{2}[\alpha \tilde{Y}-0.5 Y]\right]}{d A_{f}}=\left(\frac{\partial\left[\frac{1}{2}[\alpha \tilde{Y}]\right]}{\partial A_{f}}+\left[\frac{\partial\left[\frac{1}{2}[\alpha \tilde{Y}]\right]}{\partial K_{f}}\right]\left[\frac{d K_{f}}{d A_{f}}\right]\right)>0 \text {. Hence, improvements in }
\end{aligned}
$$

foreign productivity increases the net incomes of both Foreign and State capital under the bargaining regime. Since $\tilde{Y} \underset{A_{f} \rightarrow \infty}{\longrightarrow}$, for high enough foreign productivity both $U_{b}>U_{n}$ and $F C>0$. Q.E.D.

Proposition 2 shows that improvement in foreign productivity may provide the impetus for adopting a limited reform under which Foreign capital is allowed to enter in a controlled way. Instead of fully unleashing the competitive forces of a market economy, the profitability and thus the inflow of Foreign investment are determined by a bargaining process between State and Foreign capital.

Notice the difference between Propositions 1 and 2. If the surplus from the reform is divided by competitive market forces, a higher productivity of Foreign capital may reduce State capital's income if State and Foreign capital are substitutes. This in turn implies that when Foreign and State capital are substitutes, State capital will refrain from reform altogether if the reform results in a fully competitive market economy. Since the conflicts of interest between State capital and the other parties concerning the reform arise when State capital and Foreign capital are substitutes, we examine this particular case in detail through an example.

Figure 1 reports the outcome in the bargaining regime, where $\alpha=0.3 ; \rho=0.35 ; L=13 ; K_{d}=0.4 ; A_{d}=1$. The upward-sloping curve $\mathrm{OB}$ traces the combinations of foreign productivity and Foreign capital inflow $\left(A_{f}, K_{f}\right)$ that solve 
the first-order condition (11) for the equilibrium inflow of Foreign capital. The downward-sloping contours are the net iso-rent curves of Foreign capital [equation (12)]. Moving upward and rightward is associated with higher rents. The bold contour is the zero foreign rent curve. The dashed curve plots combinations of $\left(A_{f}, K_{f}\right)$ for which State capital is indifferent between no reform and controlled reform [i.e., $U_{n}=U_{b}$ ]. State capital benefits from a controlled reform above and to the right of the dashed curve. Below the bold curve a controlled reform is not effective, as Foreign capital would not break even, and the foreign direct investment is zero. Thus, a controlled reform would induce foreign direct investment if and only if $A_{f}>A_{0} .{ }^{9}$ Because State capital shares the net surplus from the reform with Foreign capital, we conclude that the reform occurs if and only if $A_{f}>A_{0}$.

Figure 2 reports the outcome in the competitive regime for the same parameters of $\alpha, \rho, L, K_{d}$, and $A_{d}$. The downward-sloping contours in Figure 2 show State capital's net gain from the reform, and the upward-sloping curve OE shows the supply of Foreign capital in the competitive regime. 10 As is clear from Figure 2, State capital loses from the reform for all parameter values of $A_{f}$. Hence, State capital should oppose the reform independently of the productivity gap between the domestic and State capital $\left(A_{f}-A_{d}\right)$. The main difference between the

9 Note that for a foreign productivity level between $A_{i}$ and $A_{0}$ a controlled reform is not feasible -- State capital would benefit, but Foreign capital would not break even.

10 Curve OE in Figure 2 traces $\frac{\alpha \kappa_{f} \tilde{Y}}{K_{f}}=r_{f}$, the equilibrium condition for the inflow of Foreign capital in the competitive regime. The downward-sloping contours show the value of $\alpha \kappa_{d} \tilde{Y}-0.5 Y$, the net gain to State capital from adopting the reform. 


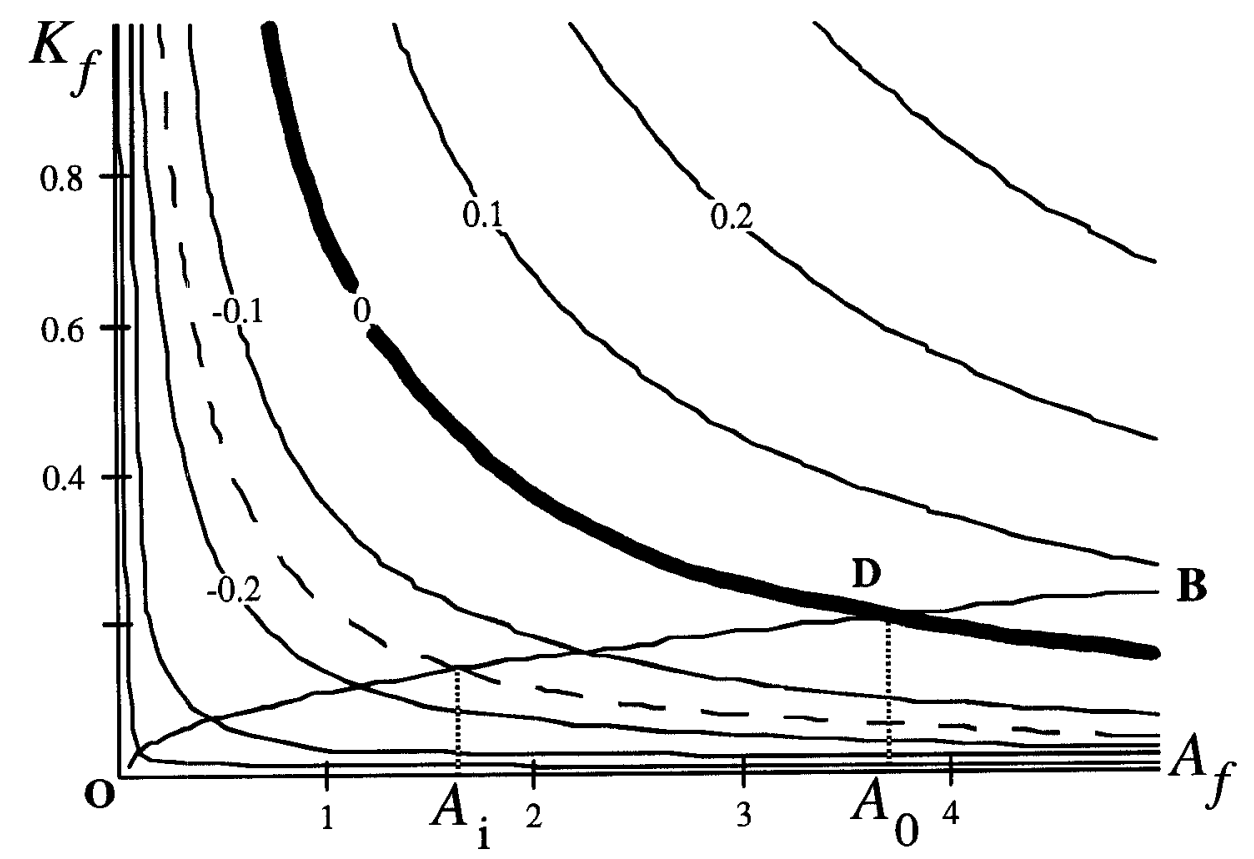

Figure 1: The bargaining regime

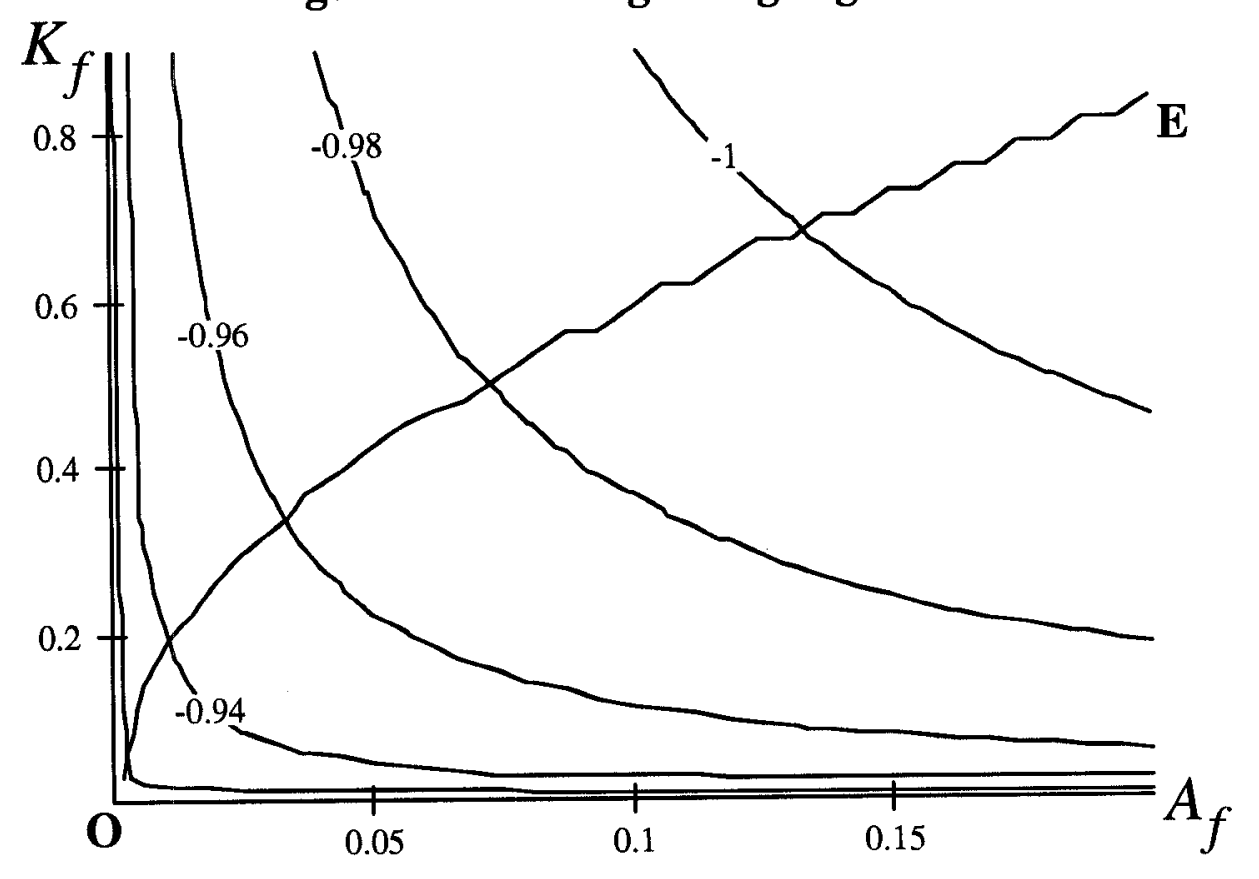

Figure 2: The competitive regime

Both figures report the simulation for the case where

$$
\alpha=0.3 ; \rho=0.35 ; L=13 ; K_{d}=0.4 ; A_{d}=1
$$


bargaining regime and the competitive regime is that moving upwards and to the right in Figure 1 (the bargaining regime) is associated with a rise in the income gain of State capital from the reform, whereas the opposite applies in Figure 2 (the competitive regime). In contrast, Foreign capital always gains from the increase in its productivity both under the competitive regime and under the bargaining regime. Hence, a competitive system fails to reward State capital for the reform when State and Foreign capital are substitutes. ${ }^{11}$

Comparison of State capital's income under the bargaining regime and under the competitive-market regime shows that switching to the bargaining regime is tantamount to forcing a side-payment from Foreign capital to State capital. The side-payment equals

$$
\alpha\left[0.5 \tilde{Y}_{b}-\kappa_{d} \tilde{Y}_{c}\right]+[0.5 Y] / 2
$$

where $\tilde{Y}_{b}$ and $\tilde{Y}_{c}$ denote output if the reform is adopted in the bargaining regime and in the competitive regime, respectively. 12 Equations (13) and (14) reveal that,

11 Another notable difference between these two regimes is that Foreign investment in the competitive regime is higher than in the bargaining regime. This follows from the observation that, for any given foreign investment, Foreign capital's marginal income in the competitive regime exceeds its counterpart in the bargaining regime by a factor of $\frac{1}{0.5 \alpha}>1$.

12 Note that $\tilde{Y}_{b}$ is the output (2) evaluated for the case where foreign investment is determined by $\frac{0.5 \alpha^{2} \kappa_{f} \tilde{Y}}{K_{f}}=r_{f}$, the first-order condition in the bargaining regime, whereas $\tilde{Y}_{c}$ is the output (2) evaluated for the case where foreign investment is determined by $\frac{\alpha \kappa_{f} \tilde{Y}}{K_{f}}=r_{f}$, the first-order condition in the competitive regime. 
under the bargaining regime, a part of State capital's income is proportional to $0.5 Y$ -- its income prior to the reform (as this income determines its disagreement point). In addition, State capital gets part of the net surplus attributed to total capital (State capital plus Foreign capital). Thus, in the bargaining regime, the output share accruing to State capital is independent of the substitutability/complementarity between Foreign and State capital (see equation (8)). In contrast, in the competitive regime, the post-reform income of State capital is

$$
\frac{\partial \tilde{Y}}{\partial K_{d}} K_{d}=\alpha \kappa_{d} \tilde{Y}=\alpha L^{1-\alpha}\left(A_{d} K_{d}\right)^{\rho}\left\{\left(A_{d} K_{d}\right)^{\rho}+\left(A_{f} K_{f}\right)^{\rho}\right\}^{\frac{\alpha}{\rho}-1}
$$

The inflow of Foreign capital and the increase in the productivity of Foreign capital reduce the income of State capital if and only if State capital and Foreign capital are substitutes: $\alpha<\rho \leq 1$. Thus, if Foreign capital and State capital are substitutes, as in Figures 1 and 2 where $\alpha=0.3<\rho=0.35$, State capital is reluctant to institute the reform in the competitive regime. Yet, for a high enough productivity gap between State capital and Foreign capital, $\left(A_{f}-A_{d}\right)$, State capital will unambiguously adopt the reform in the bargaining regime, as it gets part of the net surplus created by inflow of Foreign capital. 


\section{Concluding remarks}

In this paper, we have constructed a model which may explain a noncompetitive strategic behavior of authorities towards foreign direct investment. The imposition of a non-competitive distribution of surpluses through bargaining is equivalent to extracting 'side payments' from Foreign capital in exchange for the 'privilege' of investing in the emerging market. While this process induces an inefficient allocation of resources relative to the outcome determined under a fully competitive and liberalized economy, it may be the only practical way to reform an economy as long as the ruling elite has the power to control such development. 


\section{References}

Alesina, Alberto and Allan Drazen. 1991. "Why are stabilizations delayed?" American Economic Review, 81: 1170-1188.

Feldman, David H. and Ira N. Gang. 1996. "Revenue motives and trade liberalization," Review of International Economics 4(3), pp. 276-281.

Fernandez Raquel and Dani Rodrik. 1991. "Resistance to Reforms," American Economic Review, 81: 1146-1155.

Gelb Alan, Gary Jefferson and Inderjit Singh. 1993. "Can communist economics transform incrementally? The experience of China," NBER Macroeconomic Annual, pp. 87-132.

Hillman, Arye L. 1982. "Declining Industries and Political-Support Protectionist Motives, " American Economic Review; 72(5), December, pp. 1180-87.

Jefferson, Gary H., Thomas G. Rawski and Yuxin Zheng. 1992. "Growth, efficiency, and convergence in convergence in China's State and collective industry," Economic Development and Cultural Change, 40: 239-266.

Rodrik, Dani. 1992. "The rush to free trade in the developing world: why so late? why now? will it last?", NBER Working paper \# 3947.

Rodrik, Dani. 1996. "Understanding Economic Policy Reform," Journal of Economic Literature, 34: 9-41.

Romer, Paul. 1994. "New goods, old theory, and the welfare costs of trade restrictions," Journal of Development Economics, 43: 5-38.

Tornell, Aaron. 1993. "Reform from within and trade liberalization," unpublished manuscript, Harvard University.

Wei, Shang-Jin. 1992. "Gradualism versus Big Bang: Speed and Sustainability of Reforms," unpublished manuscript, Harvard University. 